\title{
Le savoir-prendre
}

Enquête sur l'estimation des objets

\section{Christian Bessy et Francis Chateauraynaud}

\section{OpenEdition}

\section{Journals}

Édition électronique

URL : https://journals.openedition.org/tc/648

DOI : $10.4000 /$ tc. 648

ISSN : 1952-420X

Éditeur

Éditions de l'EHESS

\section{Édition imprimée}

Date de publication : 1 novembre 1993

ISSN : 0248-6016

\section{Référence électronique}

Christian Bessy et Francis Chateauraynaud, «Le savoir-prendre », Techniques \& Culture [En ligne], $20 \mid$

1993, mis en ligne le 05 janvier 2006, consulté le 29 septembre 2022. URL : http://

journals.openedition.org/tc/648 ; DOI : https://doi.org/10.4000/tc.648

Ce document a été généré automatiquement le 29 septembre 2022.

Tous droits réservés 


\section{Le savoir-prendre}

Enquête sur l'estimation des objets

Christian Bessy et Francis Chateauraynaud 